\title{
ПСИХОЛОГІЧНЕ КОНСУЛЬТУВАННЯ ФАХІВЦІВ ЕКСТРЕМАЛЬНОГО ПРОФІЛЮ НА ЕТАПІ АДАПТАЦЇ̈ ДО ПРОФЕСІЙНОЇ ДІЯЛЬНОСТІ
}

УдК: 159.9.001

\section{Афанасъева Наталя Євгенівна}

Кандидат психологічних наук, дочент, доцент кафедри психології діяльності в особливих умовах Національного університету циивільного захисту України, Харків (Украӥна)

Анотація. У статті проаналізовано проблему адаптації до професійної діяльності фахівців екстремального профілю та шляхи психологічної допомоги особистості на даному етапі професіогенезу. Професійна адаптація є складним, багатовимірним та тривалим процесом. Ї̈ психологічний супровід потребує розробки спеціальної психотехнологї консультування, яка враховує механізм адаптаційного процесу, специифіку професійної діяльності в екстремальних умовах, індивідуально-психологічні особливості фахівців. Запропонований підхід виявився ефективним більшою мірою для адаптаційних процесів у сфері сочіальної взаємодії з суб 'єктами професійної діяльності. Також у фахівців-клієнтів суттєво підвищилися психічна стійкість $i$ поведінкова регулящія, адекватність сприйняття оточуючих та власної особистості. В иілому психоконсультативні сесї сприяють розвитку готовності змінювати поведінку відповідно до актуальної ситуації, тобто поводитися адекватно.

Ключові слова: професійна адаптація, фахівці екстремального профілю, психологічне консультування.

\section{Постановка проблеми у загальному}

вигляді. Професійна адаптація це процес пристосування особистості до вимог діяльності. Адаптація до професійної діяльності фахівців екстремального профілю є складним, динамічним, внутрішньо суперечливим процесом, протікання якого залежить від великої кількості об'єктивних та суб'єктивних факторів. Вона передбачає формування позитивної професійної мотивації, вироблення індивідуального стилю діяльності, трансформацію де- яких психологічних особливостей особистості тощо. Одним з основних завдань психологічного забезпечення службової діяльності є оптимізація процесу адаптації працівників до умов служби.

Аналіз останніх досліджень і публікацій. Проблема адаптації фахівців екстремального профілю діяльності розглядалася такими вченими, як: А. В. Барабанщиков, М. І. Бородін, А. Д. Глоточкін, М. І. Дяченко, Ю. П. Зуєв, А. Т. Іваницький, В. П. Каширін, Ю. Я. Кі- 
ршин, Н. І. Конюхов, Б. В. Кузьменко, В. В. Нечипоренко, В. В. Собольников, М. І. Томчук, Н. Ф. Феденко та іншими.

Але слід відзначити, що проблема психологічного консультування фахівців екстремального профілю, які мають утруднення первинної адаптації до діяльності, майже не досліджувалася вітчизняними вченими.

У своєму дослідженні ми спираємося, в першу чергу, на роботи сучасних українських психологів $з$ теорії та практики надання психологічної допомоги (А. Ф. Бондаренко, П. П. Горностай, С. В. Васьковска, Н. В. Чепелєва, Т. С. Яценко та ін.), а також психології діяльності в особливих умовах (М. І. Томчук, Ю. А. Олександровський, Г. А. Балл, М. Д. Левітов, Ю. М. Швалб, М. С. Корольчук, А. М. Столяренко, О. В. Тімченко та ін.).

Мета даної статті - аналіз підходів до технології психологічного консультування фахівців екстремального профілю на етапі первинної адаптації до професійної діяльності.

Виклад основного матеріалу дослідження. У дослідженні брали участь фахівці екстремального профілю діяльності: пожежнірятувальники, що проходять службу у рятувальних підрозділах різних областей України (Харківська, Київська, Дніпровська, Одеська, Чернігівська, Житомирська); інспектори патрульної поліції м. Харкова; інспектори Харківського прикордонного загону Східного регіонального управління Прикордонної служби України.
Професійна адаптація фахівців даної категорії характеризується додатковим освоєнням професійних можливостей (знань і навичок), а також формуванням професійно необхідних якостей особистості, позитивного ставлення до своєї роботи. Важливим аспектом професійної адаптації є прийняття людиною професійної ролі. При цьому ефективність професійної адаптації значною мірою залежить від того, наскільки адекватно людина сприймає свою професійну роль, а також свої професійні зв'язки і стосунки.

3 точки зору практичної діяльності найбільший інтерес становить період первинної адаптації до умов служби в екстремальних умовах. У новачків відбувається зміна поведінкових стереотипів, зустріч 3 новими людьми, ознайомлення з усталеними звичаями і традиціями в службових колективах. Змінюється режим дня та система харчування, підвищується рівень фізичних навантажень, що зумовлює перебудову як енергетичних, обмінних процесів, так і усталених динамічних стереотипів, звичок поведінки. Одні працівники справляються 3 подібними ситуаціями цілком самостійно, іншим необхідна допомога психолога. При цьому дуже важливо враховувати, що стан здоров'я для роботи в екстремальних умовах молодих людей, на тлі зростаючих навантажень на особовий склад, часом не дозволяє без шкоди для психіки долати тяготи служби.

Визначити можливість виникнення 
труднощів в адаптації можна провівши психологічний аналіз службової та бойової діяльності фахівців екстремального профілю. Причин таких труднощів кілька. Службова діяльність є однією зі специфічних форм людської діяльності. 3 психологічної точки зору, вона поєднує в собі аспекти навчання (заняття за програмою професійної підготовки), праці (різні види господарських робіт), спорту та бойових дій в екстремальних умовах. До того ж професії екстремального профілю базуються, врешті-решт, на глибоких переживаннях соціального порядку.

У професіях цієї категорії можна спостерігати й елементи романтизму, створювані несподіванкою, непередбачуваністю, нерегламентованістю професійної поведінки.

Особливу роль в ефективності діяльності, а отже, і сприятливій психологічній адаптації, грає зниження дій негативних факторів на психіку особового складу: страху, паніки, прийняття помилкових рішень, прояву недисциплінованості тощо. Специфічна діяльність особового складу характеризується тим, що фахівці працюють в екстремальних умовах, в умовах ризику для життя. Їх праця пов'язана 3 великою емоціональністю, обумовленою такими особливостями діяльності:

- безперервним нервово-психічним напруженням, спричиненим систематичною роботою в незвичній обстановці;

- постійною загрозою життю і здоров'ю;

- труднощами, обумовленими необхідніс- тю проведення робіт в обмеженому просторі, що ускладнює дії, порушує звичні способи просування, робочі пози: просування поповзом, робота лежачи тощо;

високою відповідальністю кожного при відносній самостійності дій і рішень щодо врятування життя людей, дорогого обладнання та інших матеріальних цінностей;

наявністю несподіваних і раптово виникаючих перешкод, що ускладнюють виконання бойового завдання;

- дискомфортним станом через знаходження в робочому одязі та спорядженHi.

Доведено, що тривожне напруження є однією $з$ причин виникнення психологічної дезадаптації.

Аналіз психічного стану фахівців на чергуванні говорить про те, що у деяких осіб спостерігаються: надмірна схвильованість, підвищена емоціональна напруженість, поява нав'язливих думок: «а раптом я загину», «отримаю травму ... отруєння ... радіоактивне зараження» і т.п.

У структурі адаптивних реакцій присутні скарги фізіологічного характеру: на підвищену стомлюваність, млявість, давлючий головний біль, зниження пам'яті, спостерігаються вегетативні порушення: пітливість, тремор, тахікардія, коливання артеріального тиску та інші.

У випадках посилення астенічних про- 
явів, додавання депресивних розладів дезадаптація може досягти рівня психогенних реакцій, що характеризуються тривожноемоційними та стресовими розладами (виніс поранених та обпечених людей, смерть або каліцтво товариша по роботі, смерть або каліцтво дитини чи осіб, врятувати яких не було можливості); значними фізичними навантаженнями, обумовленими високим темпом робіт з порятунку людей, використанням засобів індивідуального захисту тощо;

- депресивним синдромом, який розвивається на тлі слабо виражених соматичних захворювань. У цей період починають переважати особистісні характерологічні форми дезадаптації, можуть розвиватися соматизовані депресії, психосоматичні захворювання, декомпенсуватися органічні захворювання, формуватися патології особистості.

Перераховані психічні стани спостерігаються не тільки у пересічних бійців, а й у працівників начальницького складу. Більш того, виявляється, що психічні стани у начальницького складу проявляються не менше чітко, ніж у рядових. Особливість передробітничих станів начальницького складу полягає в тому, що вони можуть транслюватися підлеглим. Наприклад, яскраво виражена передробітнича лихоманка начальника варти (частини) може вивести пожежного перед виконанням завдання зі стану бойової готовності, i, навпаки, бойова готовність начальника варти (частини) вселяє упевненість у підлеглих i сприяє їх кращому стану перед майбутніми діями.

Результати дослідження фахівців екстремального профілю у процесі добового чергування показали, що у частини осіб виявляються значні зміни показників психічного стану відносно вихідного рівня. Так, після завершення чергування у рятувальників був виявлений ряд розладів, що характеризувалися почуттями внутрішньої напруги, дискомфорту (50\%), зниженим настроєм (60\%), відчуттями шуму, тяжкості в голові (70\%), млявістю (83\%). У частини осіб були відзначені дратівливість, неспокій, зниження апетиту, підвищена чутливість (гіперестезія); у деяких - немотивована веселість, що супроводжувалася моторною загальмованістю.

Таким чином, психічний стан у фахівців на чергуванні завдає негативного впливу на загальний психічний стан, викликаючи появу у значної кількості осіб характерних психопатологічних феноменів і знижуючи рівень функціонального стану організму в цілому.

Сприятлива психологічна адаптація до умов служби залежить в першу чергу від індивідуально-психологічних особливостей особистості. Зокрема, були визначені такі якості особистості, що значно впливають на успішність засвоєння професії екстремального профілю: сила нервової системи за збудженням, тривожність, мотивація та схильність до ризику $[2 ; 3]$.

Успішність адаптації до впливу чинників реальної загрози життю і збереження професійного здоров'я демонструють ті, кому 
притаманна виразність наступних характеристик:

- сфформованість механізмів психічної саморегуляції;

- $\quad$ комунікативні здібності;

- збереження орієнтації на дотримання норм поведінки, незважаючи на зазнані значні психоемоційні навантаження.

Оптимізація адаптаційного процесу професійної діяльності спрямована на скорочення термінів адаптації та досягнення відповідного рівня адаптованості, при якому можлива реалізація заданої ефективності та надійності роботи. Це здійснюється як шляхом прямого впливу на їі механізми, так і непрямим впливом, тобто шляхом зміни зовнішніх і внутрішніх умов професійної діяльності.

Специфіка консультування фахівців екстремального профілю діяльності вимагає розробки спеціального підходу, що враховує наступні аспекти:

- $\quad$ короткостроковість;

- $\quad$ допомога повинна мати результат «тут i зараз» — вже на момент іiі надання;

- відсутність мотивації клієнта на отримання психологічної допомоги (як правило);

- $\quad$ особливість контексту психологічної роботи.

Для здійснення консультування даної категорії клієнтів необхідно знаходити:

- $\quad$ актуальні (найбільш значущі зараз) проблеми для даного клієнта; психологічні аспекти, на які можна вплинути безпосередньо і відносно швидко; психологічні підходи і методи для найбільш ефективної роботи в даних умовах [1].

Психологічне консультування фахівців даної категорії на етапі адаптації до професійної діяльності включає два основних напрями:

1. Створення умов для умовно адаптованих фахівців, спрямованих на формування адекватної внутрішньої картини адаптації.

2. Системна робота 3 клієнтами, що мають труднощі в адаптаційному процесі, в особистісно-смисловій, мотиваційній та психорегулятивній сферах, спрямована на формування адекватної реалістичної самооцінки, професійної ідентичності та «Я-концепції», професійної мотивації, підвищення комунікативного потенціалу й освоєння прийомів вольової та емоційної саморегуляції.

Консультант разом з клієнтом аналізує три гіпотези щодо проблем адаптації до професійної діяльності клієнта: диференціальну (у чому полягає проблема?), динамічну (чому виникли проблеми?) і прецедентну (як може бути вирішена проблема?). Отримані при аналізі факти (думки, почуття, поведінкові реакції) формують базис для створення стратегій, які повинні привести до вирішення проблем і повноцінної реалізації різних аспектів професійної діяльності - інтелектуального, особистісного, соціального і власне професійного.

У консультуванні 3 питань адаптації 
застосовуються еклектичні методи.

Спочатку з метою ідентифікації проблеми використовуються клієнт-центроване i центроване на розвитку консультування. На другій стадії процесу домінують психодинамічні методи, такі як інтерпретація, роз'яснення причин виникнення проблем. На заключній стадії процесу використовуються трейтфакторний та біхевіоральний підходи, щоб допомогти клієнту у вирішенні проблем.

Психологічна підтримка і допомога полягають у знятті стану тривоги, формуванні позитивної установки на подолання труднощів, розвитку почуття затребуваності та соціальної захищеності, актуалізації резервних можливостей фахівця.

Дослідження впливу психологічного консультування на адаптивні процеси проводилося з фахівцями екстремального профілю, стаж роботи яких не перевищував 1 року і чиї психологічні проблеми в основному були пов'язані з адаптацією до професійної діяльності, нового колективу і т.п. Кількість респондентів - 37 осіб (рятувальники, поліцейські, прикордонники).
Для дослідження динаміки рівня адаптивності особистості до та після психологічного консультування використовувалися Багаторівневий особистісний опитувальник (БОО) «Адаптивність» А.Г. Маклакова і С.В. Чермяніна; «Шкала соціальної адаптивності» Ч. Снайдера в адаптації О.Г. Посипанова. Результати відображені в таблицях 1, 2 .

Отримано значущі відмінності між показниками за шкалою «Нервово-психічна стійкість» ( $\mathrm{p} \leq 0,05$ за критерієм Стьюдента). Тобто внаслідок проведеного консультування у досліджуваних значно підвищилися психічна стійкість і поведінкова регуляція, адекватність сприйняття оточуючих та власної особистості. Показники за іншими шкалами підвищилися, але не досягли рівня значущості. Такі зміни пов'язані з тим, що на консультативних сесіях досить багато уваги приділялося проблемі саморегуляції, як в теоретичному, так і в прикладному аспекті. Освоювалися спеціальні прийоми, обговорювалися і моделювалися ситуації, в яких необхідно використовувати різні техніки, що сприяють стабілізації психічного, емоційного стану фахівців.

Таблиия 1

Показники адаптивності кліснтів до та після психологічного консультування (стани)

\begin{tabular}{|c|c|c|c|c|}
\hline Шкали & $\begin{array}{c}\text { До ПК } \\
(\mathbf{n = 3 7 )}\end{array}$ & $\begin{array}{c}\text { Після ПК } \\
(\mathbf{n = 3 7 )}\end{array}$ & $\mathbf{t}$ & $\mathbf{p}$ \\
\hline Нервово-психічна стійкість & 4,5 & 6,7 & 2,31 & 0,05 \\
\hline Комунікативні особливості & 3,8 & 5,4 & 1,68 & - \\
\hline Моральна нормативність & 6,2 & 6,9 & 0,74 & - \\
\hline $\begin{array}{c}\text { Особистісний адаптаційний потенці- } \\
\text { ал }\end{array}$ & 4,8 & 6,3 & 1,58 & - \\
\hline
\end{tabular}




\section{Показники соціальної адаптивності кліснтів до та після психологічного консультування}

(бали)

\begin{tabular}{|c|c|c|c|c|}
\hline Шкали & $\begin{array}{c}\text { До ПК } \\
\mathbf{( n = 3 7 )}\end{array}$ & $\begin{array}{c}\text { Після ПК } \\
\mathbf{( n = 3 7 )}\end{array}$ & $\mathbf{t}$ & $\mathbf{p}$ \\
\hline Конформність & $3,2 \pm 1,2$ & $5,4 \pm 1,9$ & 2,31 & 0,05 \\
\hline Лабільність & $2,8 \pm 1,0$ & $5,1 \pm 1,8$ & 2,42 & 0,04 \\
\hline Креативність & $3,5 \pm 1,3$ & $3,9 \pm 1,4$ & 0,42 & - \\
\hline
\end{tabular}

Отримано значущі відмінності між показниками досліджуваних за шкалами: «Конформність» (p $\leq 0,05$ за критерієм Стьюдента), «Лабільність» $(\mathrm{p} \leq 0,05)$. Показники за цими шкалами стали значно вищими після проведення консультування. Оскільки мова йде про соціальні якості особистості, такий результат ми вважаємо цілком очікуваним. Психоконсультативні сесії сприяють розвитку готовності змінювати поведінку відповідно до сформованої ситуації. До початку психологічного консультування означені фахівці були схильні поводитися ефективно тільки в одній, «звичній» групі, що не забезпечувало достатню адаптацію, крім того, вони були мало чутливі до особливостей поточної взаємодії, до настрою і переживань інших людей. У ході психологічної роботи досить багато уваги приділялося опрацюванню особливостей соціальної поведінки, формуванню оптимального поєднання комунікативних знань, умінь і навичок, що й зумовило отримані результати психодіагностики.

Для дослідження особливостей адаптаційного процесу фахівців до та після психологічного консультування була використана «Методика діагностики соціальнопсихологічної адаптації» К. Роджерса, Р. Даймона, результати наведені в таблиці 3 .

Таблиия 3

Показники соціально-психологічної адаптації клієнтів до та після психологічного консультування (\%)

\begin{tabular}{|c|c|c|c|c|}
\hline Шкали & $\begin{array}{c}\text { До ПК } \\
(\mathbf{n = 3 7 )}\end{array}$ & $\begin{array}{c}\text { Після ПК } \\
(\mathbf{n = 3 7 )}\end{array}$ & $\boldsymbol{\varphi}$ & $\mathbf{p}$ \\
\hline Адаптація & 53,8 & 63,5 & 0,74 & - \\
\hline Прийняття інших & 51,2 & 72,8 & 1,65 & 0,05 \\
\hline Інтернальність & 43,4 & 59,6 & 1,24 & - \\
\hline Самоприйняття & 52,1 & 68,4 & 1,25 & - \\
\hline Емоційний комфорт & 44,9 & 67,3 & 1,71 & 0,05 \\
\hline Прагнення домінувати & 55,7 & 65,7 & 0,76 & - \\
\hline
\end{tabular}


Отримані результати вказують на те, що після консультування значущо підвищилися такі показники, як «прийняття інших» (p $\leq$ 0,05 за критерієм Фішера) та «емоційний комфорт» $(\mathrm{p} \leq 0,05)$. Це означає, що клієнти стали більш сприятливими до інших людей, менш конфліктними та боязкими у контактах. Вони відчувають себе емоційно комфортно в різних ситуаціях, принаймні в тих, які раніше викликали у них зайве напруження. Ми вважаємо, що це сприятиме їх більш швидкій адаптації і до професійної діяльності, до професійного спілкування.

Висновки. Дослідження динаміки адаптаційних процесів та якостей особистості після психологічного консультування показало, що найбільших змін зазнала сфера, пов'язана 3 соціальною взаємодією. Фахівці-початківці, які отримали психологічну допомогу психолога-консультанта, стали більш стійкими в складних напружених ситуаціях, у тому числі і соціальної взаємодії. Вони стали більш конформними та лабільними в умовах групової взаємодії, тобто більш терпимими та уважними відносно інших членів групи, причому не тільки тієї, яка є для них значущою, референтною. У зв'язку з цим підвищився і рівень емоційного комфорту, який вони відчувають у спілкуванні з колегами та іншими людьми.

\section{Перспективи подалыших розвідок у} даному напрямі. Розробити психотехнологію консультування фахівців екстремального про- філю, які мають проблеми професійного розвитку на різних етапах професіогенезу.

\section{Список використаних джерел:}

1. Афанасьєва Н. С. Організація психологічного консультування фахівців екстремального профілю діяльності / Н. Є. Афанасьєва // Проблеми сучасної психології : збірник наукових праць Державного вищого навчального закладу «Запорізький національний університет» та Інститут психології ім. Г.С. Костюка НАПН України / за ред. С. Д. Максименка, Н. Ф. Шевченко, М. Г. Ткалич. - Запоріжжя : ЗНУ, 2014. - №1(5). - 134 с. - С. 24 30.

2. Балл Г. А. Понятие адаптации и его значение для психологии личности / Г. А. Балл // Вопросы психологии. 1989. №1. - C. 92-100.

3. Самсонов А. П. Психология для пожарных: психологические основы подготовки пожарных к деятельности в экстремальных условиях / А. П. Самсонов. - Пермь: Пермское книжное издательство, 1999. - С. 38-54.

\section{References (Transliteration):}

1. Afanaseva N. E. OrganIzatsIya psihologIchnogo konsultuvannya fahIvtsIv ekstremalnogo profIlyu dIyalnostI / N. E. AfanasEva // Problemi suchasnoYi psihologIYi : zbIrnik naukovih prats Derzhavnogo vischogo navchalnogo zakladu «ZaporIzkiy natsIonalniy unIversitet» ta Institut psihologIYi Im. G.S. Kostyuka NAPN UkraYini / za red. S. D. Maksimenka, N. F. Shevchenko, M. G. Tkalich. - ZaporIzhzhya : ZNU, 2014. -\#1(5). - 134 s. - S. 24-30.

2. Ball G. A. Ponyatie adaptatsii i ego znachenie dlya psihologii lichnosti / G. A. Ball // Voprosyi psihologii. - 1989. \#1. - S. 92-100.

3. Samsonov A. P. Psihologiya dlya pozharnyih: psihologicheskie osnovyi podgotovki pozharnyih $\mathrm{k}$ deyatelnosti $\mathrm{v}$ ekstremalnyih usloviyah / A. P. Samsonov. - Perm: Permskoe knizhnoe izdatelstvo, 1999. - S. 38-54. 


\section{Afanaseva Natalia}

Candidate of Psychological Sciences, Docent, Associate Professor at the Department of Psychology of activity in special circumstances NUCDU, Kharkov (Ukraine)

\section{PSYCHOLOGICAL CONSULTATION OF SPECIALISTS OF EXTREME KIND OF ACTIVITY DURING THE ADAPTATION PHASE TO PROFESSIONAL ACTIVITY}

\section{ABSTRACT}

The problem of adaptation to professional activity of specialists of extreme kind of activity and the steps of psychological assistance to an individual at this phase of professional development are analyzed in the article. Professional adaptation is complex, multidimensional and long process. Its psychological support requires special psycho technology, consultation that takes into account the mechanisms of adaptation, the specificity of professional activity in extreme conditions, personality traits of specialists.

Psychological consultation of specialists of this category during the adaptation phase to professional activity includes two main directions:

- $\quad$ Providing conditions for relatively adapted specialists aimed at forming effective internal adaptation.

- Methodical work with patients who have difficulties with the adaptation, personal semantics, motivation and psychoregulation, aimed at forming of realistic self -esteem, professional identity and "selfconcept", professional motivation, also it aimed at improving communication poten- tial and at developing and strengthening self-control.

The study of the dynamics of the level of personality adaptability before and after psychological counseling showed that as a result of the counseling conducted, the psychological stability and behavioral regulation, the adequacy of the perception of others and their own personality significantly increased.

Such changes are due to the fact that during the advisory sessions a lot of attention was paid to the problem of self-regulation, both in the theoretical and in the applied aspect. Mastered special receptions, discussed and simulated situations in which it is necessary to use different techniques that help stabilize the mental, emotional state of specialists.

Customers have become more favorable to other people, less conflicting and timid in their contacts. They feel emotionally comfortable in different situations, at least in those that previously caused them unnecessary stress. We believe that this will facilitate their faster adaptation to professional activities, to professional communication.

The suggested approach is more effective for adaptation in sphere of social interaction with subjects of professional activity. Also, mental health and behavioral regulation, selfperception and the perception of others of the specialists-patients significantly improved.

Key words: professional adaptation, specialists of extreme kind of activity, psychological 
consultation.

\section{Афанасьева Наталья Евгеньевна}

Кандидат психологических наук, доцент, доцент кафедры психологии деятельности в особых условиях Национального университета гражданской защить Украины, Харьков (Украина)

\section{ПСИХОЛОГИЧЕСКОЕ КОНСУЛЬТИРОВАНИЕ СПЕЦИАЛИСТОВ ЭКСТРЕМАЛЬНОГО ПРОФИЛЯ НА ЭТАПЕ АДАПТАЦИИ К ПРОФЕССИОНАЛЬНОЙ ДЕЯТЕЛЬНОСТИ}

Аннотация. В статье проанализирована проблема адаптации к профессиональной деятельности специалистов экстремального профиля и пути психологической помощи личности на данном этапе профессиогенеза. Профессиональная адаптация является сложным, многомерным и длительным процессом. Ее психологическое сопровождение требует разработки специальной психотехнологии консультирование, которая учитывает механизм адаптационного процесса, специфику профессиональной деятельности в экстремальных условиях, индивидуальнопсихологические особенности специалистов.

Психологическое консультирование специалистов данной категории на этапе адаптации к профессиональной деятельности включает два основных направления:

1. Создание условий для условно адаптированных специалистов, направленных на формирование адекватной внутренней картины адаптации.
2. Системная работа с клиентами, имеющими трудности в адаптационном процессе, в личностно-смысловой, мотивационной и психорегулятивной сферах, направленная на формирование адекватной реалистической самооценки, профессиональной идентичности и «Я-концепции», профессиональной мотивации, повышение коммуникативного потенциала и освоение приемов волевой и эмоциональной саморегуляции.

Изучение динамики уровня адаптивности личности до и после психологического консультирования показало, что в результате проведенного консультирования психологическая стабильность и поведенческая регуляция, адекватность восприятия окружающих значительно увеличились.

Такие изменения связаны с тем, что в ходе консультативных сессий большое внимание уделялось проблеме саморегуляции как в теоретическом, так и в прикладном аспекте. Клиенты освоили специальные приемы, обсуждали и моделировали ситуации, в которых необходимо использовать разные методы, которые помогают стабилизировать психическое, эмоциональное состояние.

Предложенный подход оказался эффективным в большей степени для адаптационных процессов в сфере социального взаимодействия с субъектами профессиональной деятельности. Также у специалистов-клиентов существенно повысились психическая устойчивость и поведенческая регуляция, адекват- 
ность восприятия окружающих и собственной

личности.

Ключевые слова: профессиональная

адаптация, специалисты экстремального про-

филя, психологическое консультирование. 